\title{
農薬生物活性の新展開
}

\section{New Development of Bioactivity of Pesticides}

光合成色素生合成系をターゲットにした新規除草剂の創製

一カロテノイド生合成を阻害するプラストキノン生合成阻害剂の開発 関野景介 $(388)$

ネオニコチノイドの選択毒性の分子基盤

作物保護においては, さまざまな防除手段を適切に順序 だて，組み合わせた総合管理の実行が推奨されている，農 薬は, すべての防除手段の中で効果が最も確実で, 低コス トであり, 現在農作物の安定生産のために, 必須の資材に なっている，農薬のもつ生物活性を戋場で最大限に発揮さ せるためには至適製剤や適切な施用法の開発, 確立も重要 である.

薬剤の開発において, 生物検定者の役割は単に合成化合 物を選抜するだけではない.いかにして特徴ある化合物を 見つけだすか，いかにして育て上げるか，いかにして上手 く活性を引き出すか, さらに社会的要請である農業生産の 系内外に対する負荷の低減をいかにして計るかなどの課題 に総合的に取りくまねばならない。

農薬生物活性研究会は, 農薬の生物活性をメインに仕事 をしている会員が集まって, 1984 年に発足してからこれま で, 生物サイドから見た「農薬の効果, 特性, 作用機構, 試験方法等に関する知見」の啓蒙のために, 毎年, 大きな テーマのもとに, 殺虫剤, 殺菌剤および除草剤を関するシ ンポジュウムを独自に開催して来た. 生物活性評価法, 生 物の多様性と農薬創製, 発生環境と農薬の開発, 薬剤の耐 性·抵抗性, 生物農薬, 薬効の変動要因, 総合防除や新剂の 開発経緯などが主なテーマである，最近は「農薬開発の新 しい流れ」のテーマのもとに生物農薬もとりあげている.

今回は, 「農薬生物活性の新展開」の総合テーマのもとに 5 つの話題提供を戴いた。いずれも今日的に話題性の高い ものである. 低環境負荷, 低毒性で高活性の新剂開発を狙 う場合の対象有害生物におけるターゲットサイトとの関係 を生理生化学的アプローチの基盤に立って論じたものであ る.

\footnotetext{
\#第 27 回大会シンポジウムをとりまとめた解説

* T321-8505 宇都宮市峰町 350 宇都宮大学野生植物科学研 究センター
}

関野景介氏：光合成の色素合成系をターゲットにした除 草剂は現在全除草剤の 16\%位を占めているが，今後次第に 増加するものと見込まれている。それらには，クルロフィ ル生合成阻害剤(プロトックス), カロテノイド生合成阻害 剂およびプラストキノン生合成阻害剂がある。ここではプ ラストキノン生合成阻害剤, ビシクロオクタン系の水稲除 草剂, ベンゾビシクロンの作用機構, 作用特性, および開 発の経緯について述べた。

松田一彦氏：殺虫剂のネオニコチノイドは昆虫のニコチ ン性アセチルコリン受容体に対して選択的にアゴニストと して作用する。そ選択毒性は, 化合物がもつ物理化学的 性質と受容体（アセチルコリン結合蛋白質, 水溶性）の構 造をつきあわせて考えることにより説明できると述べた。

河野義明氏：低毒性殺虫剤の開発を目指して, 昆虫には 高濃度で存在するが, 哺乳類には存在しない二糖類, トレ ハロースに着目した。トレハロースの加水分解醭素トレハ ラーゼ阻害剤の害虫制御への利用の可能性について述べ た。

仲下英雄氏：病原菌の感染により植物体内でサリチル酸 生合成が誘導され, 健全部においても全身獲得抵抗性 (SAR)が示されるが, 薬剤によっても SAR が誘導される. いくつかの薬剤について SARの機構について述べた. 植 物ホルモンのブラシノステロイドの病害抑制効果は SAR とは異なる抵抗性を誘導することによる。

汲田泉氏：殺菌剂の開発を目指して細胞膜構成成分とし て重要なステロール生合成系をターゲットとして選定し, そのためにスクワレンエポキシダーゼ阻害作用を持つ化合 物を探索した．活性を示した化合物は類似した立体構造を 有していた。

(*竹内 安智記) 